\title{
Deliberative Qualities in Televised Election Debates: The Influence of the Electoral System and Populism
}

\author{
Sofie Marien ${ }^{\mathrm{a}, \mathrm{b} *}$, Ine Goovaerts ${ }^{\mathrm{a}}$ and Stephen Elstub ${ }^{\mathrm{c}}$ \\ ${ }^{a}$ Centre for Political Science Research, University of Leuven, Leuven, Belgium; ${ }^{b}$ Department \\ of Political Science, University of Amsterdam, Amsterdam, The Netherlands \\ ${ }^{c}$ School of Geography, Politics and Sociology, Newcastle University, Newcastle-upon-Tyne, \\ United Kingdom.
}

\begin{abstract}
Concerns are raised repeatedly about the quality of televised debates. Both a country's electoral system and the presence of populist candidates have been argued to influence the deliberative qualities of these debates. By using an extended version of the Discourse Quality Index, this study conducts a content analysis of 12 televised election debates in Germany, the Netherlands, and the United Kingdom between 2009 and 2015. Against expectations, results show that politicians in multiparty systems do not use more justifications for policy positions and are not more respectful in the televised debates. Rather, this study uncovers a clear populist challenge to key deliberative debate qualities across party systems. Left- and right-wing populist politicians take more positions without proper justification and right-wing populists' presence in the televised debates increases the number of disrespectful interactions, lowering the deliberative qualities of the televised debates in different electoral contexts.
\end{abstract}

Keywords. Deliberation, Discourse Quality Index, Incivility, Populism, Televised Debates, Political Information Environments 


\section{Introduction}

Televised debates enable politicians to communicate their policy positions on different issues to the electorate, which in turn allows voters to make informed choices and to hold politicians accountable (Aalberg and Jenssen 2007; Holbrook 1999; Van der Meer et al. 2015). Democracy requires deciding what to do, but also why to do it, which means we need a 'ratio' or grounds for political decisions (Goodin 2008). Televised debates could offer a particularly good platform within election campaigns to communicate policy positions and its underlying ratio. However, this requires specific deliberative qualities such as the provision of justifications for the proposed policy positions, respect towards other policy positions, and civil exchanges with other politicians (Steenbergen et al. 2003).

Despite the popularity and proliferation of televised debates across Western Europe, we know particularly little about the deliberative qualities of these debates and how contextual factors influence these qualities. To better understand which factors shape different aspects of political information environments, cross-national research is needed (Anstead 2016; Hallin and Mancini 2004; Kriesi 2004; Nir 2012; Racine Group 2002; Van Aelst et al. 2017: 20). Crossnational research documented higher levels of deliberative qualities of parliamentary debates in multiparty systems (e.g. Bächtiger and Hangartner 2010; Lord and Tamvaki 2013; Steiner et al. 2004). Does the same pattern emerge in other less researched arenas such as mediated communication?

In this study, we investigate the deliberative qualities of televised debates cross-nationally. We reason that electoral rules fostering multiparty systems offer stronger incentives to communicate collaboratively in parliamentary but also in mediated communication arenas. If politicians anticipate they may have to work together after the elections, they will have a larger 
incentive to follow deliberative norms such as justifying one's positions and interacting in a respectful way with each other in parliament but also in television studios. We do not expect that these systemic incentives affect all debate participants to the same extent. The ideology and communication style of populist politicians run counter to several deliberative qualities (Wyss et al. 2015: 14; see also Abts and Rummens 2007; Moffitt 2016). Therefore, we do not expect the debate interventions of populist politicians to be more deliberative in multiparty systems. In all countries, we expect that the presence of populist politicians in televised debates lowers its deliberative qualities. In sum, we expect that differences in electoral contexts and the presence of populist politicians in the televised debates influence deliberative debate qualities such as the provision of justifications and respect.

We investigate the deliberative qualities of the main televised debates between political leaders that are held prior to the general elections. We rely on deliberative democratic theory to conceptualise and operationalise three important deliberative debate qualities: the justification of one's policy positions, showing respect towards each other's positions and civil interactions with each other (Steenbergen et al. 2003). We selected three countries with differences in electoral rules and populist presence (Germany, the Netherlands, and the United Kingdom). In each country we study four debates i.e. two debates in two electoral campaigns between 2009 and 2015 .

In what follows, we first provide an overview of the literature on the importance of televised election debates and its deliberative qualities as well as the expected cross-national differences. Subsequently, we describe the data and method, which is followed by the presentation of the results and the conclusion. 


\section{The Importance of Deliberative Qualities in Televised Election Debates}

Whereas most types of electoral campaign discourse are one-sided, a key advantage of televised debates is the possibility to compare political candidates side by side (Jamieson and Adasiewicz 2000). Viewers are not selectively exposed to the political information of only one political candidate or party (Lang and Lang 1961), which can enable voters to make more informed decisions (Benoit et al. 2003; Jamieson and Birdsell 1988). Research indeed shows that after watching televised debates voters are better informed about the policy positions and the personality of politicians (Benoit et al. 2002; Holbert et al. 2002; Holbrook 1999; Van der Meer et al. 2015). They are more aware which topics are currently being discussed, have increased issue knowledge, are better able to formulate their opinion, and are more inclined to discuss politics with others (Aalberg and Jenssen 2007; Benoit et al. 2003; Cho and Choy 2011). Consequently, there is little doubt about the potential and importance of televised debates in informing the electorate.

To facilitate learning effects, it is important televised debates have certain deliberative qualities such as the respectful provision of arguments. This becomes clear when looking at the assumptions of commonly used normative models of political representation, such as the responsible party model. This model stipulates that if popular will is to be reflected in government policy then political parties should have different policy positions and voters must know what these differences are, so that the electoral outcome can be interpreted as a policy mandate (Goodin, 2008: 227; Thomassen, 1994: 251-252): 'What sort of a mandate a government can claim - what a government is entitled to do in office - depends heavily upon how the campaign messages are conveyed' (Goodin 2008: 224). As such televised debates could significantly increase democratic quality. However, the presence of these prerequisites is debated. 
There is extensive concern about politicians' lack of clear argumentation and the use of oneliners (Annenberg Debate Reform Working Group 2015; Zarefsky 1992). Mediatisation in general, and the format of televised debates in particular, encourage politicians to provide short answers and express their views in soundbites to attract the attention from citizens and media outlets. As the interest in political television programs is generally low, in part because of the increased media choice (Prior 2005), politicians and media outlets try to find successful ways to spread their message and attract voters' attention. Extensively explaining policy positions and long, 'boring' debates do not fit this 'media logic' (Brants and Van Praag 2006). However, using simplified statements hinders voters to get a substantive understanding of the policy positions of politicians.

Another concern focuses on the predominance of negative campaigning in elections i.e. a strategy used to win votes by criticizing one's opponent (Ansolabehere and Iyengar 1995; Geer 2006; Lau et al. 2007). Critiquing other candidates is a key part of democracy and a core element of any political debate (Geer 2006) and is prevalent in televised debates (Airne and Benoit 2005; Benoit 2001; 2007; 2013). Yet uncivil interactions such as interrupting others, personal attacks, or humiliating others and their viewpoints violates social norms, hindering the information function of debates. Moreover, incivility in political discourse is found to lower the perceived legitimacy of oppositional views (Mutz 2007), political trust (Mutz and Reeves 2005), and to increase political cynicism (Cappella and Jamieson 1997).

In sum, the beneficial effects of exposure to televised debates depend on its deliberative qualities such as the presence of justifications for policy positions, respect towards other 
positions and civility ${ }^{1}$. Accordingly, the quality of these televised debates merits more scholarly attention. In this study, we aim to gain insight into the deliberative qualities of televised debates across Western Europe. Recent studies have started to assess the deliberative quality of different types of political discourse (Davidson et al. 2017; Lord and Tamvaki 2013; Pedrini 2014) and media content (Van der Wurff et al. 2016; Wessler and Rinke 2014). This study builds on this recent scholarship and broadens the scope by studying the deliberative qualities of televised debates and contextual factors that facilitate or hinder these. ${ }^{2}$

\section{Deliberative Debate Qualities from a Comparative Perspective}

Comparing the deliberative qualities of parliamentary debates, power-sharing systems, such as Switzerland, perform better than majoritarian systems such as the United Kingdom (Bächtiger and Hangartner 2010; Steiner et al. 2004). The discourse of MEPs from consensus democracies is also found to be more deliberative compared to the discourse of MEPs from majoritarian democracies (Lord and Tamvaki 2013). Does a similar cross-national pattern emerge comparing televised debates? While in many countries televised debates have become an important part of the electoral campaign, comparative research into the deliberative qualities of these debates is lacking. Drawing on the rich cross-national insights into the deliberative qualities of parliamentary debates, we expect that a system that encourages power-sharing increases the deliberative qualities of televised debates.

\footnotetext{
${ }^{1}$ We distinguish two types of disrespect, i.e. towards a policy vs. a person (Brooks and Geer 2007). The term (dis)respect is used to refer to (dis)respectful statements expressed towards the policy positions of another politician. The term (in)civility is used to refer to (dis)respectful statements towards another politician as a person, e.g. personal attacks.

${ }^{2}$ We focus on the provision of justification for policy positions, respect towards other politicians' positions and civility as key deliberative qualities that are beneficial to democratic performance and have raised concerns recently. There are other deliberative qualities that merit study as well. Yet we do not expect that all ideal-type elements of deliberation will be present during a televised debate in which politicians strive to make their positions on different issues clear. Party leaders will generally try to convince the electorate to vote for them by distancing themselves from the issue positions of the other politicians in the debate. Constructive politics or opinion change amongst the party leaders themselves, for example, is something we do not expect to occur in these debates (Davidson et al. 2017).
} 
In particular, expectations about the nature of future government formation can incentivise more or less deliberative communication in the pre-electoral debates. Proportional representation systems generally result in multi-party systems (stimulating the emergence and existence of many parties). Many political parties gain seats in parliament, generally leading to large, often unpredictable, coalition formations. Politicians will anticipate that they may have to work together after the elections, increasing the incentives to follow deliberative norms such as respectfully justifying one's positions. On the other hand, plurality systems generally result in two-party systems (marginalizing the smaller parties), and are designed to decrease the need for coalition partners. As such plurality and proportional systems offer different incentives for deliberative communication. In sum, we expect the more deliberative discourse observed in parliaments in proportional systems to spill-over to other arenas such as more deliberative discourse in debates during electoral periods.

Accordingly, we study three West European parliamentary democracies with varying electoral rules and ensuing party systems and government formations: The Netherlands, UK, Germany. The electoral rules used in the Netherlands result in a large number of parties obtaining seats in parliament (e.g. 11 parties in 2012) and a very fragmented party system (e.g. because of the low $0.67 \%$ electoral threshold). Before the elections it is not clear which specific coalition government is likely to be formed and many possible combinations are likely (Jacobs 2018). We expect this to create high incentives to communicate collaboratively (See Appendix A).

At the other end of the continuum, we selected the United Kingdom. The electoral rules used in the UK facilitate the possibility that one political party can govern alone, i.e. the Conservative or Labour party. More recently we can observe deviations from the long-term 
history of single party governments with the 2010 Cameron-Clegg coalition government. Despite these recent changes, the plurality rule system favours established major parties with safe seats, making gaining significant parliamentary representation still extremely challenging for new parties (Democratic Audit UK 2016: 4). The 2015 election for instance resulted in more than $85 \%$ of the seats being divided between the two main political parties which have dominated the political scene for the last 70 years (Powell et al. 2015). While the UK system is becoming increasingly multi-party, the simple plurality electoral system clearly insulates the Conservatives and Labour from the smaller parties, making coalitions unusual. This offers little incentives for collaborative communication as generally collaboration is not anticipated after the elections, especially in comparison to the Netherlands and Germany.

The electoral rules used in Germany result in a party system that is less fragmented than the Netherlands (e.g. because of higher $5 \%$ electoral threshold) but more than the UK. For instance, after the 2013 election, five political parties obtained seats in Parliament. As such the German system is classified as 'moderate PR' (Lijphart 2008: 162). Importantly, it is more predictable in Germany compared to the Netherlands which parties will form a coalition (Zittel 2018; See Appendix A).

Overall, the anticipation of coalition formation and the uncertainty surrounding it is highest in the proportional representation system in the Netherlands, lowest in the plurality system in the UK, with the mixed member proportional system in Germany falling in between the two. We expect these different contexts to influence the communication of parties along the same lines as comparative research studying the deliberative qualities of parliamentary debates. In particular, we will study three specific expectations: 
Hypothesis 1: The deliberative qualities of televised election debates are highest in the Netherlands, followed by Germany, and finally the UK

Hypothesis 1.1: Policy positions in televised election debates are justified more in more fragmented party systems

Hypothesis 1.2: Political leaders are more respectful towards each other's positions in televised election debates in more fragmented party systems

Hypothesis 1.3: Political leaders are more civil towards each other in televised election debates in more fragmented party systems

We do not expect all politicians to be affected as strongly by this electoral context. In particular, populist politicians generally share an 'ideology that considers society to be ultimately separated into two homogenous and antagonistic groups, "the pure people" versus "the corrupt elite". This thin ideology argues that politics should be an expression of the general will of the people' (Mudde 2004: 543). According to these populist politicians, this will of 'the people' can hardly be disputed. As a consequence, populist politicians criticise the debating character inherent to political decision-making and leave 'no room for disagreement and compromise' (Abts and Rummens 2007; Urbinati 1998: 117). This is expected to lead to the use of simplified, more direct and anti-establishment language (Bos et al. 2013; Canovan 1999; Moffitt 2016) that focuses on 'conflict and crises at the expense of consensus and substantive facts' (Bossetta 2017: 730). In this context, Bossetta (2017: 715) notes that 'the new wave of populist challenges is a far cry from the deliberative, temperate, and polished politicians'. Evidence from parliamentary debates in Switzerland (Wyss et al. 2015: 14) and tweets in Italy (Bracciale and Martella 2017) indeed indicate that populists are less likely than other, non-populist politicians, to justify their positions well and behave respectfully in political debates. While other, non-populist candidates, also use less deliberative elements in their political discourse, 
this non-deliberative communication style is argued to be more pronounced in the discourse of populists. Interestingly, most concerns today are about the communication of right-wing populists. As the vast majority of studies on populist communication investigate right-wing populists only, we know little about left-wing populist communication (Aalberg and de Vreese 2017). Therefore, we include both in this study. As they share the populist ideology ${ }^{3}$, we expect both to be less justified and less respectful than non-populist politicians.

This leads to the following hypotheses:

Hypothesis 2: Deliberative debate qualities are lower in the discourse of right-wing and leftwing populist candidates than in the discourse of other non-populist political candidates in televised election debates

Hypothesis 2.1: Policy positions taken by populist candidates are justified less than positions taken by other non-populist candidates

Hypothesis 2.2: Populist candidates are less respectful towards other candidates' positions than other non-populist candidates

Hypothesis 2.3: Populist candidates are less civil towards other candidates than other non-populist candidates

There are indications that televised debates including populist candidates could have a lower level of deliberative interventions from all participants compared to those debates where populists are absent. Bossetta's (2017) research on the 2014 European Union debates between Nick Clegg and Nigel Farage - the latter generally identified as a populist politician - found

\footnotetext{
${ }^{3}$ The populist ideology is mostly viewed as a thin ideology that needs to be combined with other thick ideologies to be a full ideology, e.g. nationalism for right-wing populists and socialism for left-wing populists. Left- and right-wing populists thus share the same populist ideology, but differ because there is another thick ideology attached to it (Mudde 2004).
} 
that Clegg used more personalised attacks in the second debate to try to compete with Farage more effectively. Therefore, to gain more insight into the potential populist challenge, we explore whether non-populist politicians adopt a disrespectful communication style more often when interacting with populist politicians than when they interact with other politicians.

In sum, by testing these expectations this study allows to shed light into the influence of differences in electoral contexts and the presence of populist politicians on the deliberative quality of the political information environments.

\section{Data and Methods}

Four debates per country were selected, transcribed and coded i.e. two TV election debates in every country from two recent national election periods (2009-2015). This makes the sample and selection of cases across each country comparable (i.e. same number of televised election debates within same time frame). The selection of debates aims to offer a good representation of the recent televised election debates in a country but also of the country's party system and populist presence (for an overview of the debates, see Appendix B). The unit of analyses are speech acts i.e. a part of the debate in which a demand is issued $(\mathrm{N}=1,112)$. This demand includes a policy position or proposal on what decisions should or should not be made (Steiner et al. 2004).

\section{Explanatory Variables}

We study three countries with differences in electoral rules and presence of populists in the debates. As a result of the different electoral rules, the anticipation of coalition formation and the uncertainty surrounding it is highest in the Netherlands, lowest in the UK, with Germany falling in between the two. In line with Mudde's (2004) definition and recent studies on 
populism in Europe (Mudde 2004; Rooduijn et al. 2019; Vossen 2009) the debate participants Geert Wilders (Dutch Partij Voor de Vrijheid), Rita Verdonk (Dutch Trots op Nederland), and Nigel Farage (UK Independence Party) were identified as right-wing populist candidates. Debate participants Emile Roemer (Dutch Socialistische Partij), and Gregor Gysi and Oskar Lafontaine (German Die Linke) were identified as left-wing populists. All other political candidates were identified as non-populist candidates.

\section{Deliberative Qualities Measurements}

To investigate the deliberative qualities of the televised election debates, we rely on the Discourse Quality Index (DQI) (Steenbergen et al. 2003; Steiner et al. 2004). The DQI is a theoretically-grounded measurement that allows researchers to operationalise and quantify the deliberative qualities of political discourse. Based on Habermas' discourse ethics, the authors identified several coding categories that reflect idealisations of deliberative qualities (Thompson 2008). This article focuses on two coding categories developed in the DQI, namely the level of justification for policy positions and respect. The DQI coding category includes both respect towards politicians and their positions. Since these are two different types of disrespect, i.e. towards a person vs. a policy (Brooks and Geer 2007), we decided to divide the variable into two different parts: respect towards other positions and respect towards other politicians in the debate, i.e. civility. The operationalisation of the three dependent variables is as follows:

\section{Level of Justification for Positions}

In a high-quality deliberative discourse, political leaders provide a justification for their positions (Steenbergen et al. 2003). We distinguished between three levels of justification, depending on its presence and sophistication. Code 0 is assigned when no justification is given, 
code 1 for an inferior justification (a reason $\mathrm{Y}$ is given why $\mathrm{X}$ should or should not be done, but a linkage between the two is missing) and code 2 for a qualified justification, in which a linkage is made between $X$ and $Y$ (Steenbergen et al. 2003; Steiner et al. 2004). The following example provides a typical illustration of a qualified justification for a position. In this example, Mark Rutte - political leader of the Dutch party VVD - responds to a statement voiced by another participant in the debate who states that Rutte does not consider the elderly in his austerity policy.

Mark Rutte (translated from Lijsttrekkersdebat 2012): ... 'I'll tell you two things why your story is not correct. First, the VVD raises the elderly discount because we believe it is important to sustain the purchasing power of the elderly in the Netherlands. That will be a whole fuss to get done. And second, one thousand euro net is a relatively large proportion of one's income for someone with a low income compared to someone with a high income. But we believe that when you have a system such as in the Netherlands in which higher incomes also pay higher taxes, it makes sense that when you give a tax $\underline{\text { reduction, }}$, it will be the same for everyone, because lower incomes are also affected in a much more positive sense.' [Coded as '2']

A typical instance of a proposal that is not clearly connected to a justification explaining why something should (not) be done is described below.

Nigel Farage (ITV Leaders' Debate 2015): ‘... We have doubled the national debt in the course of the last five years. Our debt repayment is bigger than our annual defence budget, and that's with interest rates close to zero. We have a massive problem here. And it seems to me that nobody's prepared to admit that what we've done is we've 
maxed out the credit cards. Yes, there's growth in the economy, but actually at some point we've got a dreadful debt repayment problem. We've got to get real. And we can cut budgets like foreign aid with, I think, popular public support.' [Coded as '1']

\section{Respect Towards Other Positions}

This indicator assesses whether politicians show (a lack of) respect when responding to each other's positions and arguments. A code 0 is given as a sign of no respect when the viewpoints of political adversaries are degraded and negative statements are explicitly uttered towards the positions of others. This code is given for instance when a politician states that the position of another debate participant is ridiculous. For speech acts in which there is a neutral way of interaction or in which respect is shown towards each other's positions, code 1 is assigned.

\section{Civility $^{4}$}

This indicator assesses respect towards other participants in the debate. Code 0 is assigned to interventions that are characterised by incivility, i.e. in which debate participants personally attack each other, utter uncivil or rude statements towards each other and ridicule each other. Code 1 is assigned for a normal or respectful way of debating with each other. The following quote illustrates an intervention in which a politician is ridiculed by Geert Wilders (translated from Dutch Premiersdebat 2012):

'Look, it is crystal clear, Mr. Rutte will continue to pay [the Greeks]. The US president once had the slogan "Yes, we can!". Your slogan seems to be "Yes, we pay!" You

\footnotetext{
${ }^{4}$ Incivility can also occur when politicians are not talking about specific proposals that should (not) be made. Therefore, additional debate interventions $(N=164)$ were identified. In these interventions, politicians react towards another politician or talk about another politician without talking about specific proposals. This led to a total amount of 1,276 speeches to analyze the level of civility.
} 
probably still believe the Tooth fairy exists, but I'll tell you Mr. Rutte: The Tooth fairy doesn't exist and we will never see the money again!' [Coded as '0']

\section{Reliability tests}

In each country, two coders coded at least $20 \%$ of the speech acts. Inter-coder reliability scores, i.e. percentage agreement and Cohen's kappa, that controls for inter-coder agreement by chance, are calculated and displayed in Appendix C. All scores are above the common thresholds for satisfactory reliability.

\section{Analysis}

First, we present the percentages of the deliberative qualities of the debates across countries. In the subsequent analysis, a Pearson's $\mathrm{Chi}^{2}$-test is performed to test whether the deliberative debate qualities are significantly different between the countries. Second, we explore variations between debate participants to gain more insight into the influence of the presence of populist politicians in the debates.

\section{Results}

\section{Cross-national investigation}

\section{Level of Justification for Positions}

Figure 1 visualises the percentages of different types of justification cross-nationally. If we look at qualified justifications - which are closest to the deliberative ideal - we observe that politicians justify their proposals to a similar extent across countries. In each country, politicians use a qualified justification for circa $50 \%$ of the positions they take. Looking at inferior or no justification, there are small differences between the countries. Contrary to the expectations, in the country with a plurality system and the least fragmented party system, the 
UK, the number of instances in which a position is taken without any justification is the lowest, followed by the Netherlands and Germany. A Pearson's Chi ${ }^{2}$ test reveals the association between the level of justification and the country under investigation is significant $\left(X^{2}=16.31\right.$, $p=0.003$; see table 1). This difference is driven by the cross-national differences in the two weakest levels of justification. In sum, hypothesis 1.1 - which stated that positions in televised election debates are justified more in countries with more fragmented party systems - does not receive support. The level of qualified justification is remarkably similar across countries and the UK has even less instances where positions are taken without any justification than the other countries.

Figure 1: Level of Justification for Positions

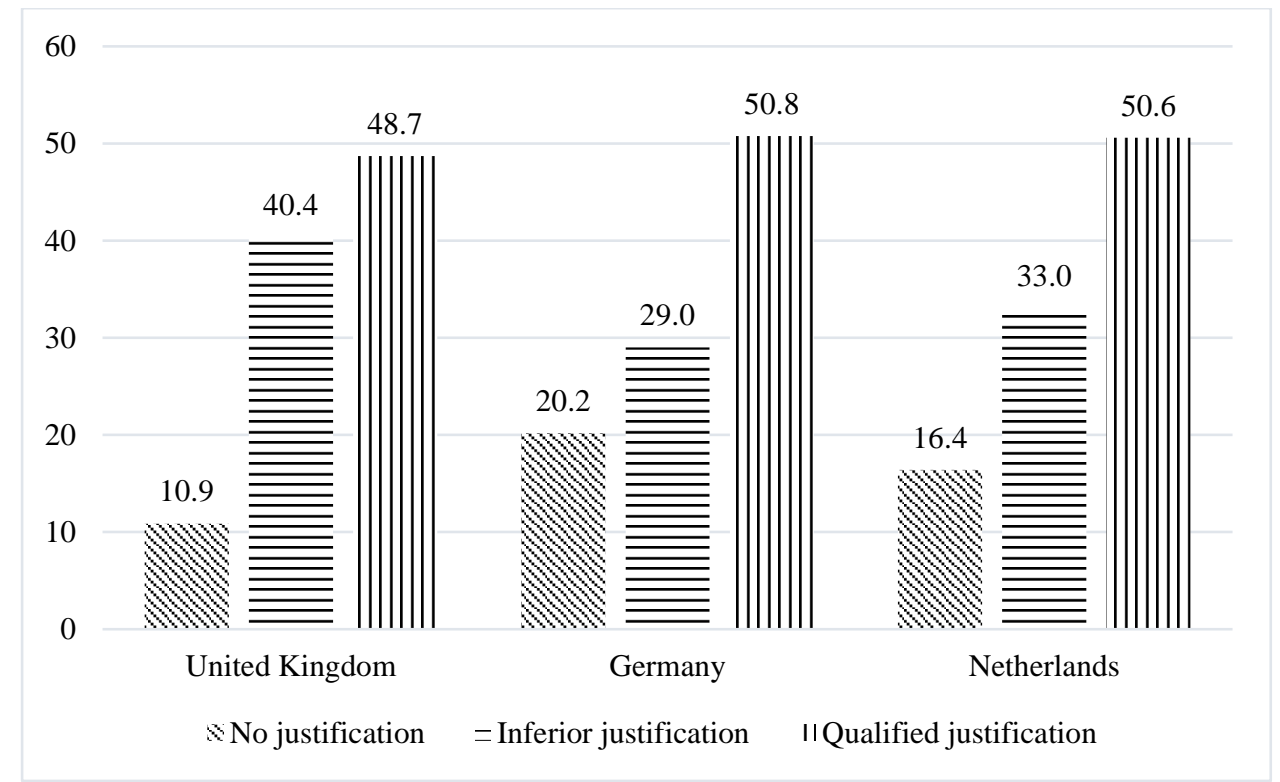

Note: $N=1097$

\section{Respect Towards Positions of Other Participants}

Figure 2 reveals that in each country at least half of the reactions to other politicians' positions are respectful. Contestation, a central element of any (good) debate, seems to occur in a rather respectful manner in televised debates. In line with the expectations, there are more instances of disrespect towards positions expressed by politicians in the UK $(49.1 \%)$ than in the more fragmented party systems of the Netherlands (42.4\%) and Germany (35.3\%). Contrary to what 
we expected, most instances of respect happen in Germany instead of the Netherlands. The Pearson's Chi²-test shows that politicians' respect towards positions of others is significantly different across countries $\left(X^{2}=12.44, p=0.002\right.$; see table 1$)$. In sum, hypothesis 1.2 does not receive full support.

Figure 2: Respect Towards Other Positions

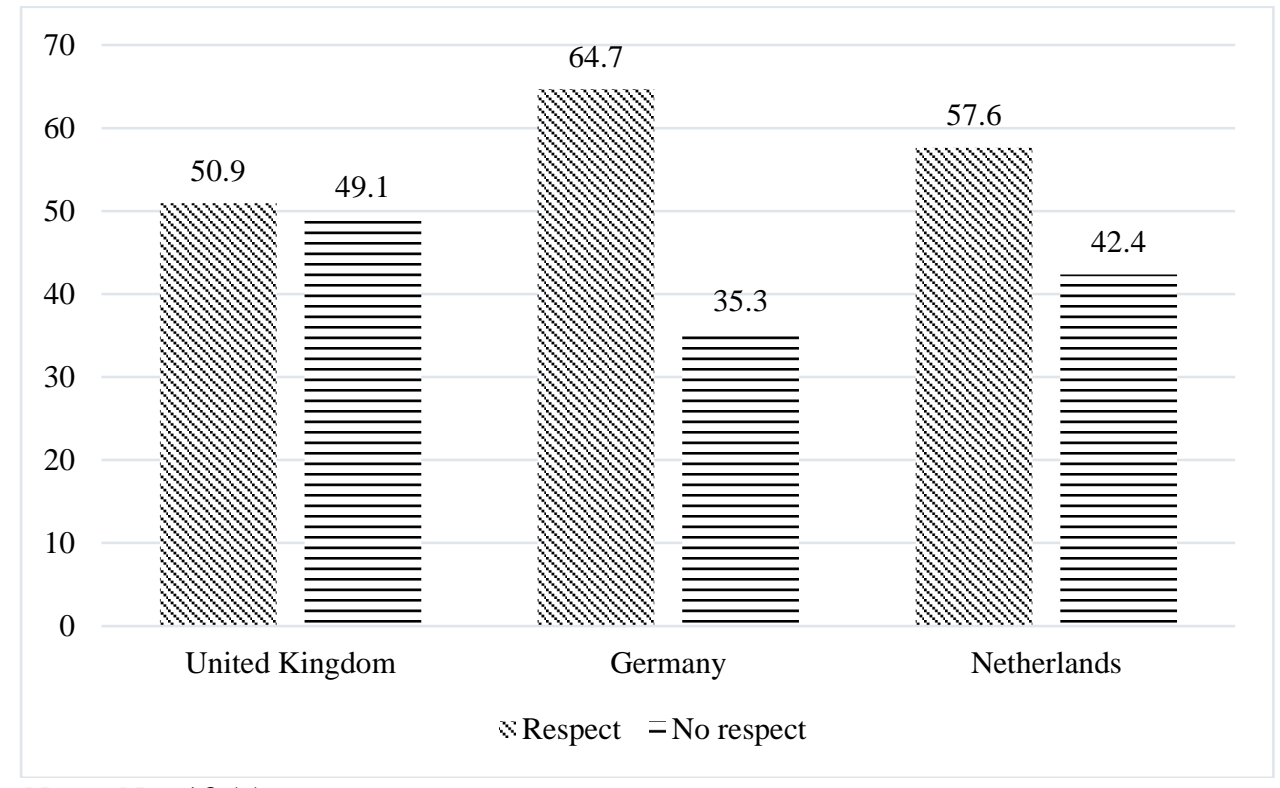

Note: $N=1055$

\section{Civility}

Figure 3 shows that the uncivil debate interventions, in which a politician ridicules or attacks other politicians, are in the minority. Across all countries, $77.6 \%$ of interventions were civil, $22.4 \%$ were uncivil. Similar to the measurement of respect towards positions, Germany has the highest level with $94.2 \%$ of interventions being civil towards other politicians. Politicians in the UK and the Netherlands have similar scores when looking at their level of incivility. With $29.5 \%$ of uncivil utterances towards politicians in the UK and $29.3 \%$ in the Netherlands, the difference in systems does not seem to matter. The Pearson's Chi ${ }^{2}$-test (see table 1) shows that the level of incivility is significantly associated with the countries $\left(X^{2}=84.88, p<0.001\right)$. In 
sum, this contradicts hypothesis 1.3 which stated that political leaders are more civil towards each other in televised election debates in more fragmented party systems such as the Netherlands.

\section{Figure 3: Civility}

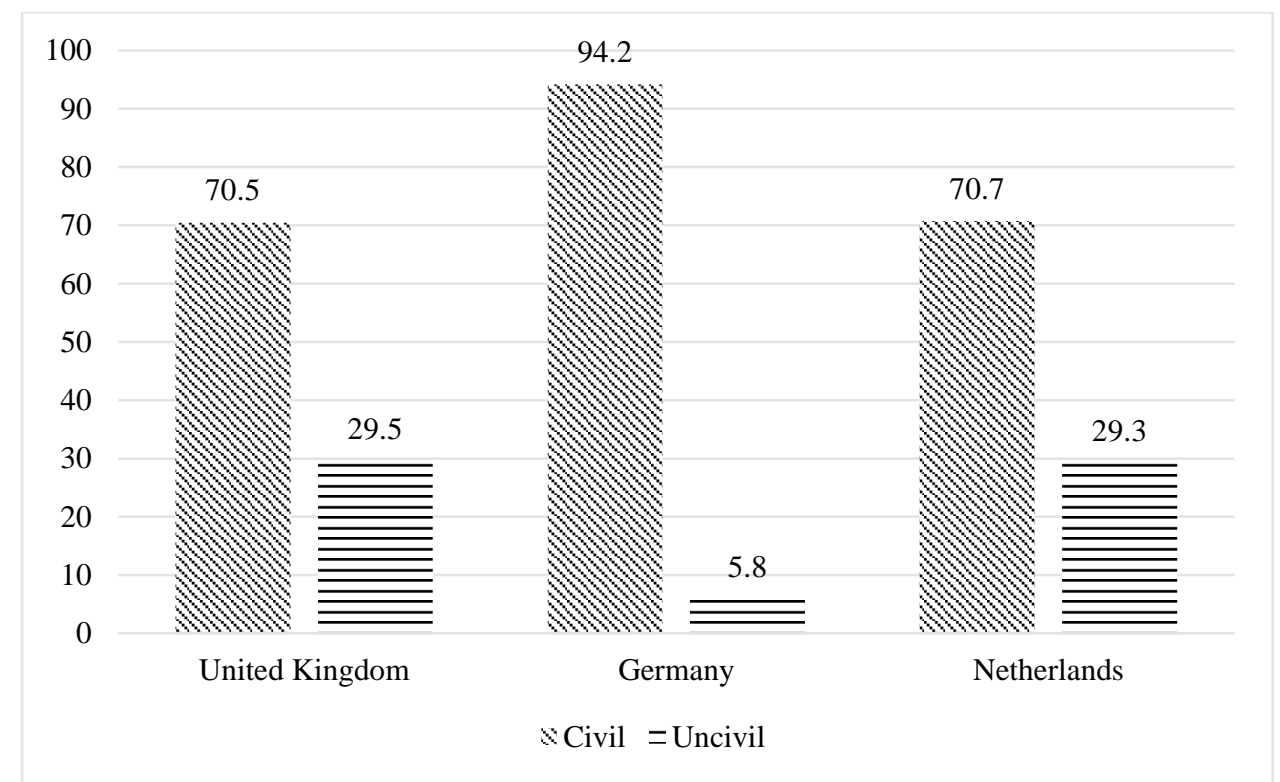

Note: $N=1266$

To conclude, the results reveal cross-national differences in the deliberative qualities of the studied televised debates. However, the results are not in line with our expectations derived from comparative studies on parliamentary debates. Germany scores best with regard to both respect variables. For level of justification, differences are small between the three countries. Politicians in more fragmented party systems are not justifying their policy proposals more. 
Table 1. Overview of Deliberative Qualities of Televised Debates According to Party System ( $X^{2}$-test)

\begin{tabular}{|c|c|c|c|c|c|c|}
\hline & UK (\%) & $\begin{array}{l}\text { Germany } \\
(\%)\end{array}$ & NL (\%) & Significance & $\begin{array}{l}\text { Best } \\
\text { performance }\end{array}$ & Strength \\
\hline $\begin{array}{l}\text { Level of } \\
\text { justification } \\
\text { for positions }\end{array}$ & & & & $\begin{array}{l}X^{2}=16.31 \\
p=0.003\end{array}$ & $\begin{array}{l}\text { No clear } \\
\text { winner }\end{array}$ & $\begin{array}{l}\text { Weak } \\
\text { (Cramer's } \\
\mathrm{v}=0.086 \text { ) }\end{array}$ \\
\hline None & 10.9 & 20.2 & 16.4 & & & \\
\hline Inferior & 40.4 & 29.0 & 33.0 & & & \\
\hline Qualified & 48.7 & 50.8 & 50.6 & & & \\
\hline $\begin{array}{l}\text { Respect } \\
\text { towards } \\
\text { other } \\
\text { positions }\end{array}$ & & & & $\begin{array}{l}X^{2}=12.45 \\
p=0.002\end{array}$ & $\mathrm{G}>\mathrm{NL}>\mathrm{UK}$ & $\begin{array}{l}\text { Weak } \\
\text { (Cramer's } \\
\mathrm{v}=0.109)\end{array}$ \\
\hline No respect & 49.1 & 35.3 & 42.4 & & & \\
\hline Respect & 50.9 & 64.7 & 57.6 & & & \\
\hline Civility & & & & $X^{2}=84.88$ & $\mathrm{G}>\mathrm{NL} \sim \mathrm{UK}$ & Moderate \\
\hline Uncivil & 29.5 & 5.8 & 29.3 & $p<0.001$ & & (Cramer's \\
\hline Civil & 70.5 & 94.2 & 70.7 & & & $\mathrm{v}=0.259)$ \\
\hline
\end{tabular}

Note: $N_{\mathrm{LJD}}=1097, N_{\mathrm{RTD}}=1055, N_{\text {Civility }}=1266$

\section{The Populist Influence}

A potential reason for the cross-national pattern we observe are the cross-national differences in populist participation in the televised debates. Not only are populist candidates expected to decrease the deliberative qualities of televised debates by their use of simplified and disrespectful messages, but there are indications that non-populist politicians behave more disrespectfully towards populists. Table 2 shows that when comparing debates with and without populist politicians participating, debates with populists are indeed (slightly) less justified and less respectful towards positions of other debate participants. Civility towards the debate participants themselves is clearly lower in the debates with populist politicians. To arrive at a more fine-grained analysis, we compare the deliberative qualities of the interventions of populist candidates with the interventions of the other candidates. 
Table 2. Comparing Debates With and Without Populist Politicians

\begin{tabular}{lcc}
\hline & Debate without populists (\%) & Debate with populists (\%) \\
\hline $\begin{array}{l}\text { Level of justification for } \\
\text { positions }\end{array}$ & & \\
$\quad$ None & 18.7 & 14.3 \\
Inferior & 28.6 & 37.0 \\
Qualified & 52.7 & 48.7 \\
& & \\
Respect towards other & & \\
positions & & \\
$\quad$ No respect & 40.1 & 43.4 \\
Respect & 59.9 & 56.6 \\
Civility & & \\
$\quad$ Uncivil & & 26.1 \\
Civil & 13.7 & 73.9 \\
\hline
\end{tabular}

Note: $N_{\mathrm{LJD}}=1097, N_{\mathrm{RTD}}=1055, N_{\text {Civility }}=1266 ; 8$ debates with populist candidates ( 4 debates in NL, 2 debates in DE, 2 debates in UK) and 4 without ( 2 debates in UK, 2 debates in Germany).

\section{Level of Justification for Positions}

The results presented in table 3 are in line with the expectations: While $52.7 \%$ of non-populist candidates use qualified justifications to argue their positions, only $37.5 \%$ and $39.6 \%$ of the positions taken by right-wing and left-wing populist politicians respectively are justified that way. Populist candidates use more inferior justifications (41.7\% and 37.8\%) than non-populist candidates $(32.9 \%)$, and justifications are also more often lacking for positions taken by populist candidates $(20.8 \%$ and $22.5 \%)$ compared to other candidates $(14.4 \%)$. The Pearson's $\mathrm{Chi}^{2}$-test shows a significant association between populism and level of justification for positions: populist candidates justify their positions less than non-populist candidates $\left(X^{2}=\right.$ $14.95 ; p=0.005$, see table 3 ), supporting hypothesis 2.1 .

\section{Respect Towards Positions of Other Debate Participants}

For respect shown by debate participants towards each other's positions, results are partially in line with the expectations. Right-wing populist debate participants express more disrespectful claims towards the positions of others $(52.2 \%)$ than non-populist participants $(42.0 \%)$. This is 
however not the case for left-wing populists, who are disrespectful towards other politicians' positions in $36.1 \%$ of the cases, meaning they are slightly more respectful than non-populist politicians in the debates. The Pearson's $\mathrm{Chi}^{2}$-test shows a significant association at the 0.10 level, which is largely driven by right-wing populists communicating most disrespectfully $\left(X^{2}\right.$ $=5.36, p=0.069$; see table 3). Moreover, the disrespectful interventions of non-populists are disproportionally targeted at the positions of right-wing populist politicians compared to the positions of the other non-populist politicians. In particular, in the debates where populist politicians were present, $67.2 \%$ of the messages by non-populists targeted at the populists are disrespectful towards their policy positions. This type of disrespect was less prominent when non-populists directed their messages at positions of the other non-populist politicians $(47.6 \%)$. Non-populist politicians were slightly more disrespectful to the positions of left-wing populists $(55.4 \%)$

\section{Civility}

For respect towards other debate participants, results are again partially in line with the expectations formulated in hypothesis 2.3: right-wing populist debate participants are more often uncivil towards other participants $(53.8 \%)$ than non-populist participants $(20.4 \%)$, but left-wing populists are less uncivil $(9.4 \%)$ than non-populist participants $\left(X^{2}=81.59, p<0.001\right.$; see table 3). Especially for this third quality criterion, the differences are substantial. Moreover, non-populist participants are also more uncivil when they target their messages at right-wing populist politicians $(48.8 \%)$ compared to when they target their messages at other politicians (33.3\%). Consequently, not only are right-wing populist participants more uncivil, but non- 
populist participants are too when they direct their messages at them. ${ }^{5}$ The incivility from both groups combined has a large overall influence on the deliberative qualities of the debates. ${ }^{6}$

Table 3. Overview of Deliberative Qualities in Televised Debates According to Populism $\left(X^{2}-\right.$ test)

\begin{tabular}{|c|c|c|c|c|c|c|}
\hline & $\begin{array}{l}\text { Non- } \\
\text { populists } \\
(\%)\end{array}$ & $\begin{array}{l}\text { Right-wing } \\
\text { populists } \\
(\%)\end{array}$ & $\begin{array}{l}\text { Left-wing } \\
\text { populists } \\
(\%)\end{array}$ & Significance & $\begin{array}{l}\text { Best } \\
\text { Performance }\end{array}$ & Strength \\
\hline $\begin{array}{l}\text { Level of } \\
\text { justification } \\
\text { for positions }\end{array}$ & & & & $\begin{array}{l}X^{2}=14.95 \\
p=0.005\end{array}$ & Non-populist & $\begin{array}{l}\text { Weak } \\
\text { (Cramer's } \\
\mathrm{v}=0.083)\end{array}$ \\
\hline None & 14.4 & 20.8 & 22.5 & & & \\
\hline Inferior & 32.9 & 41.7 & 37.8 & & & \\
\hline Qualified & 52.7 & 37.5 & 39.6 & & & \\
\hline $\begin{array}{l}\text { Respect } \\
\text { towards other } \\
\text { positions }\end{array}$ & & & & $\begin{array}{l}X^{2}=5.36 \\
p=0.069\end{array}$ & $\begin{array}{l}\text { Left-wing } \\
\text { populist \& } \\
\text { non-populist }\end{array}$ & $\begin{array}{l}\text { Weak } \\
\text { (Cramer's } \\
\text { v = 0.071) }\end{array}$ \\
\hline No respect & 42.0 & 52.2 & 36.1 & & & \\
\hline Respect & 58.0 & 47.8 & 63.9 & & & \\
\hline Civility & & & & $X^{2}=81.59$ & $\begin{array}{l}\text { Left-wing } \\
\text { populist }\end{array}$ & Moderate \\
\hline Uncivil & 20.4 & 53.8 & 9.4 & $p<0.001$ & & (Cramer's \\
\hline Civil & 79.6 & 46.2 & 90.6 & & & $\mathrm{v}=0.254)$ \\
\hline
\end{tabular}

In sum, we can observe a populist challenge. In particular, right-wing populist candidates' interventions in televised debates and the reactions to these interventions lower the deliberative quality of the televised debates. ${ }^{7}$

\footnotetext{
${ }^{5}$ This is not the case when non-populist politicians react to left-wing populist politicians: they are uncivil towards them in $25.4 \%$ of the cases.

${ }^{6}$ To investigate this, we only included those debates in which populist politicians participated, and those speech acts that were directly targeted at another politician. 653 speech acts of non-populist politicians were directed at another politician from which 502 were directed at another non-populist politician, 80 at a right-wing populist politician, and 71 at a left-wing populist politician.

${ }^{7}$ While there are differences between populist right-wing and populist left-wing parties, there are no differences between the non-populist parties according to left-right ideology regarding the three quality criteria.
} 


\section{Conclusion}

Televised political debates are an important source of information for the electorate because viewers can learn more about different political issues and policy positions. Learning is especially enhanced when politicians in these debates respectfully justify their policy positions. In this study, we assess the deliberative qualities of televised election debates in three West European parliamentary democracies. This allows to better understand the cross-national factors that shape the quality of political information environments. First, a systematic assessment of the deliberative qualities of twelve election debates reveals that debate participants most frequently offer justifications for their positions and behave overall relatively respectful. In sum, this systematic analysis qualifies the concerns about poor televised debate quality to some extent.

Second, we show that the more deliberative communication style of politicians observed in parliamentary debates in multiparty systems does not extend to televised debates. Electoral rules that foster power-sharing do not seem to enhance the deliberative qualities of televised debates. Compared to parliamentary debates, communicative practices in televised debates seem to be more transferable across different electoral systems. Campaigning might encourage a different mindset among politicians than governing, i.e. a mindset that is focused on winning office. This mindset could make politicians less willing to compromise regardless of the specific electoral system (Gutmann and Thompson 2014). Another explanation for the absence of large cross-national differences could be the eroding differences between electoral systems. For example, bipolar competition is increasingly prevalent in multiparty systems and coalitions were formed in traditional two party systems (Mair 2008: 226). In turn, we see greater similarities in electoral campaigns in different party systems including the communicative practices in televised debates. 
The cross-national difference in the presence of populists in the televised debates further explain the documented cross-national pattern. The deliberative qualities of especially rightwing populist politicians' interventions - who were present in the UK and Dutch debates, but absent in the German debates at the time - were found to be lower than the deliberative qualities of other politicians' interventions. Both right-wing and left-wing populist candidates perform worse at justifying their positions, and right-wing populists show less respect towards the other participants and their positions. This is in line with the expectations in the literature stating that the political discourse of populist candidates is more simplistic, direct and uncivil than the discourse of non-populist politicians (Canovan 1999; Bos et al. 2013; Moffitt 2016).

Interestingly the presence of right-wing populists in televised debates affects the deliberative quality of respect more than the provision of justifications. The average number of positions lacking justification and the average number of disrespectful interactions in a debate is higher because of its more frequent use by right-wing populist participants. Yet we can also observe non-populist politicians behaving more disrespectful towards right-wing populist candidates compared to their interventions towards other debate participants. Hence, right-wing populist interventions are more disrespectful but also non-populists are prone to behave more disrespectfully towards right-wing populist debaters. As a result, the influence of populist politicians on the deliberative qualities of televised debates is strongest when looking at more relational qualities such as respect.

Reflecting on these findings, we see some important areas for future research. First, a majority of the statements in the televised election debates were well-justified and respectful. Nevertheless, debate viewers might especially remember discourse elements that reflect poor 
deliberative debate qualities. One reason might be that disrespectful behaviour violates the social norms people share for a debate. The role of the media in covering these debates might be another reason. One-liners and disrespectful statements might be the parts of the debate that are more likely to be picked up more in the post-debate media coverage. Therefore, it would be fruitful, for instance, to study whether one-liners and disrespectful behaviour are more influential than higher quality interventions in remembering and covering the televised debates.

Second, we studied the presence and formal quality of justifications as a first step to deliberation and learning. We also limited ourselves to an assessment of the verbal content. It would be interesting to study the epistemic quality of these justifications and non-verbal behaviour as well. Third, we recommend future studies to consider other factors that could influence deliberative quality in debates such as the communication culture of a country (Sass and Dryzek 2014) or the gender of the participants (Maier and Renner 2018). It would also be interesting to explore why left-wing and right-wing populists behave differently. Last, while these results shed light on the deliberative qualities of televised election debates and factors that might influence it, future research should also deepen our understanding of the effects of a poor or high debate quality. Some studies already investigated the effects of incivility and transparency on different political attitudes (Mutz and Reeves 2005; De Fine Licht et al. 2014), but more research is needed that focuses on the effects of different quality criteria - such as justification(s) and respect - on what and how people learn from these debates and how it influences their image of politics. This study reveals interesting differences in the communicative practices of right-wing and left-wing populists and non-populists and the communicative reactions of non-populists to populists. There are indications that also the effects of these communicative practices differ depending on the characteristics of the politicians using it and the characteristics of the audience e.g. education level of citizens (Bos 
et al. 2013). Do right-wing populists use more disrespectful communication because it is more effective for them compared to left-wing populists and other parties? Given the rise of populist politicians who are clearly less deliberative in some aspects of their communication, it is important to gain more insights on the effect of this on the functioning of democracies. 


\section{References}

Aalberg, Toril, and Claes H. de Vreese (2017). 'Introduction: Comprehending Populist Political Communication', in Toril Aalberg et al. (eds.), Populist Political Communication in Europe. New York: Routledge, 3-11.

Aalberg, Toril, and Anders T. Jenssen (2007). 'Do Television Debates in Multiparty Systems Affect Viewers? A Quasi-experimental Study with First-time Voters', Scandinavian Political Studies, 30:1, 115-35.

Abts, Koen, and Stefan Rummens (2007). 'Populism versus Democracy', Political Studies, $55: 2,405-24$.

Airne, David, and William L. Benoit (2005). '2004 Illinois U.S. Senate debates: Keyes versus Obama', American Behavioral Scientist, 49:2, 343-52.

Annenberg Debate Reform Working Group (2015). Democratizing the Debates. Available at https://www.annenbergpublicpolicycenter.org/feature/democratizing-the-debates/ (accessed 27 June2018).

Ansolabehere, Stephen, and Shanto Iyengar (1995). Going Negative. New York: Free Press. Anstead, Nick (2016). 'A Different Beast? Televised Election Debates in Parliamentary Democracies', The International Journal of Press/Politics, 21:4, 508-26.

Bächtiger, André, and Dominik Hangartner (2010). 'When Deliberative Theory Meets Empirical Political Science: Theoretical and Methodological Challenges in Political Deliberation', Political Studies, 58:4, 609-29.

Benoit, William L. (2001). 'The Functional Approach to Presidential Television Spots: Acclaiming, Attacking, Defending 1952-2000', Communication Studies, 52:2, 109-26.

Benoit, William L. (2007). 'Determinants of Defense in Presidential Debates', Communication Research Reports, 24:4, 319-25. 
Benoit, William L. (2013). Political Election Debates: Informing Voters About Policy and Character. Plymouth: Lexington Books.

Benoit, William L., Glenn J. Hansen, and Rebecca M. Verser (2003). 'A Meta-Analysis of the Effects of Viewing U.S. Presidential Debates', Communication Monographs, 70:4, $335-50$.

Benoit, William L., Mitchell S. McKinney, and Michael T. Stephenson (2002). 'Effects of Watching Primary Debates in the 2000 U.S. Presidential Campaign', Journal of Communication, 52:2, 316-31.

Bos, Linda, Wouter van der Brug, and Claes H. de Vreese (2013). 'An Experimental Test of the Impact of Style and Rhetoric on the Perception of Right-wing Populist and Mainstream Party Leaders', Acta Politica, 48:2,192-208.

Bossetta, Michael (2017). 'Fighting Fire With Fire: Mainstream Adoption of the Populist Political Style in the 2014 Europe Debates Between Nick Clegg and Nigel Farage', British Journal of Politics and International Relations, 19:4, 715-34.

Bracciale, Roberta, and Antonio Martella (2017). 'Define the Populist Political Communication Style: The Case of Italian Political Leaders on Twitter', Information, Communication \& Society, 20:9, 1310-29.

Brants, Kees, and Philip Van Praag (2006). 'Signs of Media Logic: Half a Century of Political Communication in the Netherlands', Javnost- The Public, 13:1, 25-40.

Brooks, Deborah J., and John G. Geer (2007). 'Beyond Negativity: The Effects of Incivility on the Electorate', American Journal of Political Science, 51:1, 1-16.

Canovan, Margaret (1999). 'Trust the People! Populism and the Two Faces of Democracy', Political Studies, 47:1, 2-16.

Cappella, Joseph N., and Kathleen H. Jamieson (1997). Spiral of Cynicism. Oxford: Oxford University Press. 
Cho, Jaeho, and Sing P. Choy (2011). 'From Podium to Living Room: Elite Debates as an Emotional Catalyst for Citizen Communicative Engagements', Communication Research, $38: 6,778-804$.

Davidson, Stewart, Stephen Elstub, Robert Johns, and Alastair Stark (2017). 'Rating the Debates: The 2010 UK Party Leaders' Debates and Political Communication in the Deliberative System', British Politics, 12:2, 183-208.

De Fine Licht, Jenny, Daniel Naurin, Peter Esaiasson, and Mikael Gilljam (2014). 'When Does Transparency Generate Legitimacy? Experimenting on a Context-bound Relationship', Governance, 27:1, 111-34.

Democratic Audit UK (2016) 'How democratic are the UK's political parties and the party system?', Democratic Audit UK. Available at: http://www.democraticaudit.com/2018/08/22/audit2018-how-democratic-are-the-ukspolitical-parties-and-party-system/

Geer, John G. (2006). In Defense of Negativity: Attack Ads in Presidential Campaigns. Chicago: University of Chicago Press.

Goodin, Robert E. (2008). Innovating Democracy: Democratic Theory and Practice after the Deliberative Turn. Oxford: Oxford University Press.

Gutmann, Amy, and Dennis F. Thompson (2012). The Spirit of Compromise: Why Governing Demands It and Campaigning Undermines It. Princeton, NJ: Princeton University Press. Hallin, Daniel C., and Paolo Mancini (2004). Comparing Media Systems: Three Models of Media and Politics. Cambridge, England: Cambridge University Press.

Holbert, Lance R., William L. Benoit, Glenn J. Hansen, and Wei-Chun Wen (2002). 'The Role of Communication in the Formation of an Issue-based Citizenry', Communication Monographs, 69:4, 296-310. 
Holbrook, Thomas (1999). 'Political Learning from Presidential Debates', Political Behavior, 21:1, 67-89.

Jacobs, Kristof (2018). 'Electoral Systems in Context: The Netherlands', in Erik S. Herron, Robert J. Pekkanen and Matthew S. Shugart (eds.), The Oxford Handbook of Electoral Systems. Oxford: Oxford University Press.

Jamieson, Kathleen H., and Christopher Adasiewicz (2000). 'What Can Voters Learn from Election Debates?', in Stephen Coleman (ed.), Televised Election Debates: International Perspectives. New York: St. Martin's, 25-42.

Jamieson, Kathleen H., and David S. Birdsell (1988). Presidential Debates. The Challenge of Creating an Informed Electorate. New York: Oxford University Press.

Kriesi, Hanspeter (2004). 'Strategic Political Communication: Mobilizing Public Opinion in "Audience Democracies", in Franks Esser and Barbara Pfetsch (eds.), Comparing Political Communication: Theories, Cases, and Challenges. Cambridge, England: Cambridge University Press, 184-212.

Lang, Kurt, and Gladys E. Lang (1961). ‘Ordeal By Debate: Viewer Reactions', Public Opinion Quarterly, 25:2, 277-88.

Lau, Richard R., Lee Sigelman, and Ivy B. Rovner (2007). 'The Effects of Negative Political Campaigns: A Meta-analytical Reassessment', Journal of Politics, 69:4, 1176-209. Lijphart, Arend (2008). Thinking About Democracy: Power Sharing and Majority Rule in Theory and Practice. London: Routledge.

Lord, Christopher, and Dionysia Tamvaki (2013). 'The Politics of Justification? Applying the "Discourse Quality Index" to the Study of the European Parliament', European Political Science Review, 5:1, 27-54. 
Maier, Jürgen, and Anna-Maria Renner (2018). 'When a Man Meets a Woman: Comparing the Use of Negativity of Male Candidates in Single- and Mixed-Gender Televised Debates', Political Communication, 35:3, 433-49.

Mair, Peter (2008). 'The Challenge to Party Government', West European Politics, 31;1-2, 211-34.

Moffitt, Benjamin (2016). The Global Rise of Populism: Performance, Political Style and Representation. Stanford, California: Stanford University Press.

Mudde, Cas (2004). 'The Populist Zeitgeist', Government and Opposition, 39:3, 542-64.

Mutz, Diana, and Reeves, Byron (2005). 'The New Videomalaise: Effects of Televised Incivility on Political Trust', American Political Science Review, 99:1, 1-15.

Mutz, Diana (2007). 'Effects of "In-Your-Face” Television Discourse on Perceptions of a Legitimate Opposition', American Political Science Review, 101:4, 621-36.

Nir, Lilach (2012). 'Cross-national Differences in Political Discussion: Can Political Systems Narrow Deliberation Gaps?', Journal of Communication, 62:3, 553-70.

Pedrini, Seraina (2014). 'Deliberative Capacity in the Political and Civic Sphere', Swiss Political Science Review, 20:2, 263-86.

Powell, G. Bingham (jr.), Russel J. Dalton, and Kaare W. Strøm (2015). Comparative Politics Today: A World View. Boston, United States: Pearson Education.

Prior, Markus (2005). 'News vs. Entertainment: How Increasing Media Choice Widens Gaps in Political Knowledge and Turnout', American Journal of Political Science, 49:3, 577-92. Racine Group (2002). 'White Paper on Televised Political Campaign Debates', Argumentation and Advocacy, 38:4, 199-218.

Rooduijn, Matthijs et al. (2019). The PopuList. Available at http://www.popu-list.org (accessed 8 April2019). 
Sass, Jensen, and John S. Dryzek (2014). 'Deliberative Cultures', Political Theory, 42:1, 325 .

Steenbergen, Marco R., André Bächtiger, Markus Spörndli, and Jürg Steiner (2003).

'Measuring Political Deliberation: A Discourse Quality Index', Comparative European Politics, 1:1, 21-48.

Steiner, Jürg, André Bächtiger, Markus Spörndli, and Marco R. Steenbergen (2004).

Deliberative Politics in Action: Analysing Parliamentary Discourse. Cambridge: Cambridge University Press.

Thomassen, Jacques (1994). 'Empirical Research into Political Representation: Failing Democracy or Failing Models?', in M. Kent Jennings \& Thomas E. Mann (eds.), Elections at Home and Abroad: Essays in Honor of Warren E. Miller. Michigan, US: University of Michigan Press, 237-64.

Thompson, Dennis F. (2008). 'Deliberative Democratic Theory and Empirical Political Science', Annual Review of Political Science, 11, 497-520.

Urbinati, Nadia (1998). 'Democracy and Populism', Constellations, 5:1, 110-24.

Van Aelst et al. (2017). 'Political communication in a high-choice media environment: a challenge for democracy?', Annals of the International Communication Association, 41:1, $3-27$.

Van der Meer, Tom, Annemarie Walter, and Peter Van Aelst (2015). 'The Contingency of Voter Learning: How Election Debates Influenced Voters' Ability and Accuracy to Position Parties in the 2010 Dutch Election Campaign', Political Communication, 33:1, 136-57.

Van der Wurff, Richard, Knut De Swert, and Sophie Lecheler (2016). 'News Quality and Public Opinion: The Impact of Deliberative Quality of News Media on Citizen's Argument Repertoire', International Journal of Public Opinion Research, 30:2, 233-56. 
Vossen, Koen (2009). 'Hoe Populistisch zijn Geert Wilders en Rita Verdonk? Verschillen en Overeenkomsten in Optreden en Discours van Twee Politici', Res Publica, 51:4, 437-65. Wessler, Hartmut, and Eike Mark Rinke (2014). 'Deliberative Performance of Television News in Three Types of Democracy: Insights from the United States, Germany, and Russia', Journal of Communication, 64:5, 827-51.

Wyss, Dominik, Simon Beste, and André Bächtiger (2015). 'A Decline in the Quality of Debate? The Evolution of Cognitive Complexity in Swiss Parliamentary Debates on Immigration (1968-2014)', Swiss Political Science Review, 21:4, 636-53.

Zarefsky, David (1992). 'Spectator Politics and the Revival of Public Argument', Communication Monographs, 59:4, 411-14.

Zittel, Thomas (2018). 'Electoral Systems in Context: Germany', in Erik S. Herron, Robert J. Pekkanen and Matthew S. Shugart (eds.), The Oxford Handbook of Electoral Systems. Oxford: Oxford University Press. 